\title{
Science Diplomacy and South-South Cooperation for Emergency Response: The Case of Covid-19 pandemic in Latin America
}

\author{
Luisa Fernanda Echeverria ${ }^{1}$, Karina Elizabeth Aquino Valle ${ }^{2}$, Claudia Natalie Widmaier Müller ${ }^{3}$ \\ lecheverriaking@gmail.com,keavalle@gmail.com, claudiawid@hotmail.com \\ ${ }^{1}$ Internationalization Advisor at Servicio Nacional de Aprendizaje (SENA) in Colombia \\ 2 Project Management, Second Secretary at the Ministry of Foreing Affairs and International Cooperation, Honduras \\ ${ }^{3}$ International Relations, Foreign Trade Technique National Customs Uruguay
} DOI https://doi.org/10.22219/sospol.v6i2.11647

\begin{abstract}
Latin America is a highly culturally and socioeconomically diverse region and it has a long story dealing with a weak, inequitable, inefficient and fragmented health system. The world faces a global health crisis without precedent, where global action and solidarity are crucial. This article highlights the importance of South-South cooperation actions based on science diplomacy, from countries in Latin America, for health-related emergencies, such as the COVID-19 pandemic. As the qualitative research, this article will first present the concepts of science diplomacy and SouthSouth Cooperation; secondly it will describe how these two concepts can contribute to emergencies associated with health related situations. Then, this article will review initiatives from Latin America to address the current pandemic. Finally, the general conclusions of the article will be presented. The management of the pandemic requires the best public health strategies contributing to its containment, but also an integrated approach using the transfer of good practices between the Global South, creating a network of scientists and diplomats working together to find possible solutions to the disease. South-South cooperation in Latin America occurs mainly bilaterally, especially with other countries in the Global South. Latin America has to work as a region to generate more spaces for collaboration, addressed by governments to achieve universal health.
\end{abstract}

\section{Abstrak}

Amerika Latin adalah wilayah yang sangat beragam secara budaya dan sosial-ekonomi. Wilayah ini memiliki cerita panjang yang berurusan dengan sistem kesehatan yang lemah, tidak adil, tidak efisien, dan terfragmentasi. Dunia menghadapi krisis kesehatan global tanpa preseden, di mana aksi dan solidaritas global sangat penting. Artikel ini menyoroti pentingnya aksi kerjasama Selatan-Selatan yang berbasis diplomasi sains, dari negara-negara di Amerika Latin, untuk keadaan darurat terkait kesehatan, seperti pandemi COVID-19. Sebagai penelitian kualitatif, artikel ini akan memaparkan konsep diplomasi sains dan Kerjasama Selatan-Selatan; kedua, ini akan menjelaskan bagaimana kedua konsep ini dapat berkontribusi pada keadaan darurat yang terkait dengan situasi terkait kesehatan. Kemudian, artikel ini akan mengulas inisiatif dari Amerika Latin untuk mengatasi pandemi saat ini. Akhirnya, kesimpulan umum dari artikel tersebut akan disajikan.Penanganan pandemi membutuhkan strategi kesehatan masyarakat terbaik yang berkontribusi pada penahanannya, tetapi juga pendekatan terintegrasi menggunakan transfer praktik baik antara Dunia Selatan, menciptakan jaringan ilmuwan dan diplomat yang bekerja sama untuk menemukan solusi yang memungkinkan untuk penyakit tersebut. Kerja sama Selatan-Selatan di Amerika Latin terjadi terutama secara bilateral, terutama dengan negara-negara lain di Dunia Selatan. Amerika Latin harus bekerja sebagai kawasan untuk menghasilkan lebih banyak ruang untuk kolaborasi, yang ditangani oleh pemerintah untuk mencapai kesehatan universal.

\author{
Keywords \\ Science Diplomacy, South- \\ South Cooperation, Latin \\ America, COVID-19, \\ Emergency Response
}

\section{Article History}

Received March 13, 2020

Revised August 13, 2020

Accepted August 18, 2020

Published October 13, 2020

\section{Corresponding Author \\ Luisa Fernanda \\ Echeverria. \\ Internationalization \\ Advisor at Servicio \\ Nacional de Aprendizaje \\ (SENA) in Colombia. \\ Address: Calle 75 no. \\ 52-55, Barranquilla, \\ Colombia.}


license

\section{Introduction}

The cooperation between countries located in the Global South is not new; this form of cooperation began to become dynamic in the mid-20th century after the emancipation of countries that were colonies of countries of the North. The Global South is a block of countries located in Asia, Latin America and Africa, which share similar challenges, issues and resources. The Global South is related to a history of colonialism, periphery and rebellion. Gray \& Hills explain that as a form of resistance, the historic Bandung conference took place in the year 1955, as an important milestone for the creation of the South-South Cooperation as a political movement, which aims to challenge the political and economic landscape dominated by countries from the North.

De Renzio \& Seifert also state that another important milestone for the establishment of South-South Cooperation as it is known today was the Buenos Aires Action Plan from 1978, endorsed by the United Nations, which aimed to foster South-South and Triangular Cooperation globally. When thinking about collaborations established in the framework of South-South cooperation, they are those based on respect, the exchange of knowledge horizontally and taking into account the sovereignty of the countries involved and mutual benefit (de Renzio \& Seifert, 2014). Carrillo Roa \& Santana understand that South-South Cooperation offers flexibility for the transfer of good practices between countries, supports the preservation of the cultures and local diversities and offers a better adaptation of the cooperation to the needs of the recipients (Roa \& De Santana, 2012).

In this sense South-South Cooperation is an important expression of solidarity and unites expectations with principles and motivations (Vadell, Lo Brutto, \& Leite, 2020). Various actors play an important role in South-South cooperation: from governmental and nongovernmental entities, to multilateral organizations, universities, research centers and companies. Today, the integration of South - South cooperation in emergency situations is fundamental to create capacity building and use strategies such as science diplomacy for Science for decision making, advise and resources exchange. Carrillo Roa \& Santana explain that in the last years, Latin-American countries have identified common health related situations in the region and have started to address these challenges from a cooperative way promoting regional integration and the collaboration for this purpose with other countries from the Global South( Roa \& De Santana, 2012).

Here, science diplomacy seeks to support countries in the search for allies and resources for the execution of projects, programs and policies of national, transnational and global interest. The Swiss Academy of Medical Sciences explains the relevance of building bridges towards collaborations in health issues through science diplomacy schemes, enhancing the quality of health services provided globally and emphasizing in the use of health situations as an instrument for the improvement of international relations. Science diplomacy is also a way of representing the interests from governments in global settings and seeking support for national needs and priorities (Swiss Academy of Medical Science, 2013). In this sense, Fedoroff, states that science diplomacy is the use of scientific collaboration among nations to address the common problems facing the 21 st century and to build constructive international partnership. There are many ways that scientists can contribute to this process. The Latin American countries, based on similar cultural realities, group together to generate actions and activities for South-South cooperation in 
order to transfer knowledge, generate capacities, form human capital and strengthen science, technology and innovation schemes, especially in health issues and other situations that request emergency response (Fedoroff, 2009).

In this way the purpose of this article is to explain the reality of the present time through the experiences in Latin America countries in health-related emergency situations, emphasizing in the current experience with the COVID-19 pandemic, and how science diplomacy and South-South Cooperation in Latin-American Countries can work in challenging situations where the key is to manage and control political, economic and health solutions in question of days.

\section{Methods}

As the qualitative research, this article will first present the concepts of science diplomacy and South-South Cooperation; secondly it will describe how these two concepts can contribute to emergencies associated with health related situations. Then, this article will review initiatives from Latin America to address the current pandemic. Finally, the general conclusions of the article will be presented.

\section{Science Diplomacy}

International Relations plays a different role in the beginning of 2020 which is extremely different in the whole world. To define the term of science diplomacy in this context, it is important to address the terms of science and diplomacy. Science is known as the method for finding a solution to a problem. In other contexts, science is quite known as an experimental or applied research in order to solve the outstanding issues that afflict the world's societies. Asencio-Cabot states that science is a "body of knowledge", which is permanently under review and adjustments based on reality and context. Also according to the aforementioned author, science is a "process", which is organized and aims to solve problems; science is a "social institution", as it develops and implements programs, projects, studies and other actions, in accordance with public policies designed for this purpose and finally science is a "productive force", because through it, if it is well oriented, dynamism can be generated in the different economic sectors of a country, promoting the development of societies (Cabot, 2014).

Diplomacy can highlight important issues, agendas and interests for a country on the international spaces. This process should be carried out peacefully and horizontally, including the interests of potential cooperators in the same way. Diplomacy is the mechanism par excellence to resolve conflicts and to promote cooperation. In addition, diplomacy is also a very useful tool for business, politics, sports and other activities that involve the human being (De Alba \& Velázquez, 2018). Rusieshvili states that diplomacy is about the management of international relations through negotiations, dialogues, commitments, and other actions that promote non-violent interactions between countries. Four main aspects of diplomacy can be highlighted according to Vázquez \& González, it is about relations between states, its work is based on peaceful means, negotiation plays an important role and it usually happens in a context of plurality of interests.

According to De Alba \& Velázquez, there are two types of diplomacy, bilateral and multilateral diplomacy. The table 1 shows the types of diplomacy with concrete actions for 
Science Diplomacy that can be advanced by actors as proposed by the authors Gluckman et al (Gluckman, P., Turekian, V., Grimes, R., \& Kishi, 2017). Science diplomacy has been described by various authors and experts due to the boom and visibility it has acquired internationally in recent years, as a tool for so-called soft power among countries. According to Adolin, science diplomacy can be defined as the use of international cooperation and science in order to establish relationships between people, societies and countries (Adolin, 2020). Safdari-Ranjbar \& Elyasi explain that science diplomacy happens when countries represent themselves in international scenarios in different areas, supported by scientific data (Mostafa Safdari Ranjbar, 2019). Hassan states that science diplomacy can be used to search for solutions to problems shared between countries and build "constructive partnerships" (Hassan, 2020, p.59).

Table 1. Types of Diplomacy and related actions

\begin{tabular}{|c|c|}
\hline Types of diplomacy & Actions \\
\hline Bilateral diplomacy & 1) Establishment of agendas between two \\
& countries for joint projects and development aid \\
& 2) Solutions to natural disasters \\
& 3) Economic relations between countries that \\
& facilitate knowledge transfer and capacity building \\
& 4) Exchange of goods \\
\hline Multilateral & 1) Spaces to address regional or cross-border \\
& issues (eg. migration, natural resources). \\
& 2) Global interests and problems (Sustainable \\
& Development Goals). \\
\hline
\end{tabular}

Gluckman et al. explain that there are various actions that can be carried out through science diplomacy schemes to advance and search for solutions to national needs. National needs can be advanced through exercises of soft power, in order to put on the international agendas national issues and challenges, there are also actions aimed at national security and emergency response, where the transfer of knowledge, humanitarian aid and support to the solution of emergency situations play an important role, and finally the economic dimensions, which have the objective of facilitating processes of commercial and economic exchange (Gluckman, P., Turekian, V., Grimes, R., \& Kishi, 2017).

Balakrishnan explains that science diplomacy is still a fluid and evolving concept but can usefully applied to the role of science, technology and innovation in three dimensions: (1) Scientific advice and inputs into foreign policy making (science in diplomacy) (2) Promoting international science cooperation (diplomacy for science): and (3) Using science cooperation to improve relations between countries (science for diplomacy). To this one may add a fourth important dimension, using science and technology cooperation for sustainable development (science for sustainable development (Balakhrisnan, 2018). Also Fedoroff states that science diplomacy is the use of scientific interactions among nations to address the common problems facing humanity and to build constructive, knowledge based international partnerships (Fedoroff, 2009).

Science diplomacy requires a structure within countries for its implementation (Gluckman, P., Turekian, V., Grimes, R., \& Kishi, 2017). For this, the actors of science 
diplomacy will have to identify themselves as key stakeholders and should know their roles in this kind of actions. Scientists play an important role in this process, to find effective solutions to joint challenges. Diplomats also contribute to this process by opening-up spaces for dialogue and generating opportunities to promote cooperation. There are also other important actors in this process, such as governments, which organize work agendas for science diplomacy; multilateral organizations, with interests groups from different countries, and generate spaces to find solutions. Universities and research centers also play a role by promoting coordinated research with agendas and priorities. Private Sector creates innovation from actions and projects carried out in coordination with the government's guidelines. Nonprofit organizations and foundations support governments in the implementation of programs and projects with a practical approach, based on what is contained in the agendas. Finally, civil society is an important actor in this process by proposing issues and needs for the agendas. In the following, the concept of the Global South will be reviewed, which plays a very important role in establishing science diplomacy agendas based on horizontal work and South- South Cooperation actions.

\section{The Global South}

Dados solutions to problems together or to adapt solutions to their own contexts. Likewise, in the c\& Connel relate the concept of Global South to the terms "Third World", "Periphery" and it's related to the countries located in Latin America, Asia and Africa, which were mostly colonies from European countries. These authors emphasize that the term should go beyond highlighting underdevelopment and move towards deepening the inequalities experienced by these countries, such as little access to resources, neo imperialism and permanent social and economic changes (Dados \& Connell, 2012).

Jaramillo \& Vera explain that the term "Global South" has a double metaphorical condition: "Suffering", but also "Resistance". "Suffering" is related to all those expropriated from the south or located in the south by global logics of capital accumulation, such as immigrants, ethnic minorities, victims of sexism, homophobia and racism. Suffering has also been implanted in the form of theories, guidelines, tests and measurement instruments that have been adapted by countries in the global south, but which were generated in the North, having other cultural and social contexts (Jaramillo, J., \& Vera Lugo, 2013).

With the second metaphor "Resistance" it is meant the struggle of all the sectors that seek to position spaces to reverse and resist global political orders, as well as structural, systematic and selective violence. Resistance can also be exercised through collaborations between countries, to seek context of science and technology, resistance can be observed by building capacity of human capital, the exchange of personnel and infrastructure, and the creation of networks and platforms for joint projects and programs. The term "south" has also been used for the duality "north-south", where "north" represent rich countries and "south" the poor. The south has in this sense a negative connotation and represents poverty, corruption, lack of opportunities and little development. Aketch explains that the countries of the global south live in a situation of neo-colonialism, where their resources are still being withdrawn by northern countries.

According to the United Nations, the global south is home to the poorest and most vulnerable people on the planet. Among the challenges identified by the United Nations faced 
by the countries of the Global South, it is identified that they have volatile economies, few productive capacities, weak infrastructure, lack of trained human capital, gender inequality, large differences between the rural and urban spaces, growth of youth unemployment, environmental and social problems, among others. The concept of the Global South is also associated with ignorance, however it should be recognized that the countries of the south, being aware of their realities and contexts, can form solutions more in line with their needs (United Nations, 2016).

By sharing historical elements and common problems, the possibility of cooperation between the countries of the south increases. However, this potential has not been used to a great extent, due to political and economic situations and tensions; this is why it is necessary to establish mechanisms and incentives that promote collaboration between countries of the global south (Gustavo \& Degaldo, 2019). In the following chapter the concept South-South Cooperation will be described to properly understand the importance of the connection of both.

\section{South-South Cooperation}

Bergamaschi \& Tickner state that South-South Cooperation proposes economic and political initiatives, which may include technical cooperation, humanitarian assistance, cultural exchanges or the allocation of resources for regional integration projects (Tickner, 2017). Tshireletso also explains that one of the strategies of South-South cooperation is strengthening economic cooperation ties between the countries involved, as well as facilitating trade. Rahamane comment that South-South cooperation is an instrument to promote selfsufficiency in the countries of the South, defined as an exchange of experience between various authors, such as governments, organizations and individuals. One of the results of south-south cooperation, according to Maldonado, is the improvement in the relationships between the countries involved and sustainable economic development.

Martin-Faus explains that geographic and thematic targeting is one of the potential for South-South cooperation. This author also affirms that South-South cooperation is not only an instrument for the foreign policy of a country, but also becomes a form of international positioning of the countries of the South in the international context (Martin Faus, 2015). Chaturvedi states that a new development pact is found among the countries of the South, and not in North-South cooperation schemes, since there are no conditions for the countries receiving the cooperation (Chaturvedi, 2016). This cooperation is governed by principles such as mutual gains, collective growth and opportunities to strengthen human capital. Medina exposes that South-South cooperation is a key issue on the agendas of Latin American countries to eradicate common problems such as poverty and inequality. This type of cooperation is used to improve development, share good practices and promote partnerships in the region.

One of the most important schemes of South-South Cooperation is capacity building. The United Nations defined capacity-building as a process for developing and strengthening different aspects of the skills, instincts, abilities and resources, present in organizations and communities; this need to adapt continually in a world that is changing every day (United Nations, 2020). For this, it should be borne in mind that SDG number 17, deal with the revitalization of the Global Alliance for Sustainable Development and is committed to 
transformation from within, contains objectives for capacity building, including the increase in technology and innovation in the least developed countries and the improvement of data collection and monitoring for the achievement of the SDGs. An essential ingredient in capacity development is the transformation that is generated and maintained over time from within. Universities in particular can serve as capacity building centers through research, innovation and data collection and analysis. Such a transformation goes beyond performing tasks and changes mentality and attitudes. Therefore, the "Five Modalities of Development Compact" is an interesting and useful approach to achieve the implementation of plans and activities established in between Latin American countries (Chaturvedi, 2016). Chaturvedi, describes the essential principles and modalities of the South - South cooperation. The first one includes: respect for national, sovereignty, national ownership, independence, equality, non-conditionality, non-interference, mutual benefit and demand - driven. Otherwise, the second one includes: capacity-building, in house training, technology transfer, financial assistance (grants), lines of credit and humanitarian assistance (Chaturvedi, 2016).

\section{Picture 1. Five Modalities of Development Compact}

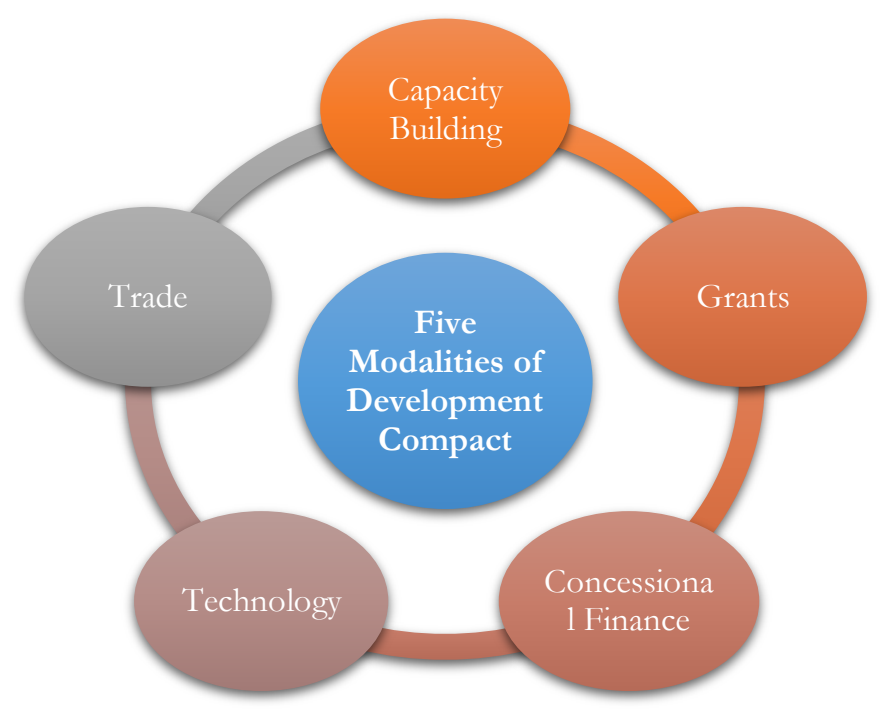

Source: Chaturvedi, 2020

How can the Development Compact model work in this context to achieve solutions to common problems and emergency situations? The concept of science diplomacy related to emergency situations like the coronavirus pandemic (COVID-19) at the end of 2019 and beginning of 2020 is a real and actual example of emergency response in the framework of South - South cooperation. Latin American countries work together to deal with this unfortunate situation which is affecting negatively different spheres of the Sustainable Development such as health and social area, political and economy. Within this framework is relevant to explain the concept of Public Health Emergency of International Concern (PHEIC) established by the World Health Organization. The PHEIC is an extraordinary event which is determined to constitute a public health risk for all states through the international spread of disease and requires a coordinated international response. The 
situation must be serious, unusual or unexpected. Another condition is that it must carry implications for public health beyond the affected State's national border and may require immediate international action (WHO, 2017).

The mission of science diplomacy in this sense is to work together with: scientists, diplomats, governments, academics and citizens to find a possible solution to this disease. Scientists all over the world are making their best effort to find medical solutions, like the creation of vaccines, in order to face this challenge. Capacity building can be understood as an activity complementary to improve science diplomacy, conflict resolution and peacekeeping operations. Community and its Member States are on course to fulfill their commitments, fight over national plans to keep their safety and security. The following section is structured in order to describe challenges and trends involving health security and emergency situations, through science diplomacy by South - South cooperation.

\section{Result and Discussion}

\section{How can South - South cooperation through Science in Diplomacy address challenges and trends involving health security?}

Today, the world is facing unexpected threats and creating new and hard to manage instabilities such as those related to the coronavirus pandemic (COVID-19). It is a fact that every day, this issue becomes more critical to address and the priority of science in diplomacy should be to ensure the effective uptake of high quality scientific advice by policymakers, hence, the governments. The scientific community must inform policymakers with up-to-date information on the dynamics of the Earth's natural and socio-economic systems. Scientists must also identify where uncertainties exist, or where the evidence base is inadequate (Royal Society, n.d.)

At this point it is important to build capacity to give and receive scientific advice; the governments should help to build the capacity to integrate the work of scientists into the foreign policies. The Royal Society states that improving the scientific capacity of delegations from developing countries is particularly important, especially for international negotiations on health and climate policy. For example, the way that the Global South governments drive the emergency regarding health problems, may lack the necessary expertise to face this challenge (Royal Society, n.d.).

Thus, it is relevant that scientists and policy makers have a better dialogue to build a bridge between the issues that science can resolve and include S\&T inputs into foreign policy making, as well as the use of international engagement in this area, in order to build capacity to face unexpected situations. In the light of all of this, it is clear that the governments should strengthen partnerships with the network of scientists between the Global South with the purpose to develop knowledge societies, across areas as diverse as medicine.

In this context, the importance of creating capacity building by delivering comprehensive emergency management practices should be well known by the governments. They also have to take charge of the threats that are facing and lift the capability to a level that they feel confident to respond, survive and even thrive from adversity, such as the coronavirus (COVID-19). The process to respond to adversity and protocol that the states lead should have the primary role to reduce the risk, however, that responsibility should be shared with other stakeholders including local government and the private sector. International cooperation also 
plays a significant role, in order to support countries in the implementation, monitoring and sharing what works in developed countries and preventing the creation of new risk.

The World Health Organization, since its creation, has been leading an effort with the purpose of promoting and protecting Health worldwide. The Head of States and Leaders of International organizations, deal every day in order to propose agendas regarding the main top priority areas of protection such as malaria, women's and children's health, tuberculosis, venereal disease, nutrition and environmental pollution. However, many of those remain on WHO's agenda today, in addition to such relatively new diseases as HIV/AIDS, diabetes, cancer and emerging diseases such as SARS (Severe Acute Respiratory Syndrome), Ebola and Zika virus. Likewise, the Sustainable Development Goal 9 aims to foster innovation and the enhancing scientific research, in all countries, in particular developing countries. In this sense, the governments of the global south, in order to achieve the 2030 Agenda, with the sustained support of international cooperation, should reinforce the idea to create capacity building in the states institutions, especially Health institutions to exchange knowledge and good practices with the developing countries.

Two initiatives involving Latin America and their collaboration with other countries in the Global South will be reviewed in the following chapter. A bilateral diplomacy initiative will be presented between the government of Colombia and China in the framework of the pandemic. Likewise, a regional integration initiative from Mercosur for an emergency fund of 16 million dollar in order to foster a national project of research, education and biotechnologies related to health and science, which is allocated against COVID-19 to improve capacity building, is shown below (Mercosur, 2020b). Both of the initiatives described are committed to improve the health situation, using South - South cooperation as a tool for emergency response, and are positive steps to alleviate the pressure of the worrying situation.

\section{Initiatives Involving Latin American Countries}

1. China's Support to the Colombian Government through the COVID-19 Pandemic by Donations and Knowledge Exchange

Since China (the epicenter of COVID-19) managed to control the crisis and stopped reporting cases of local contagion, it began to send aid to different countries, including equipment, medical workers, supplies and its medical model to various parts of the world. As reported at the end of March by the China International Development and Cooperation Agency (Cidca), the country had already provided assistance to 89 countries and four international organizations to combat the coronavirus,

Relations between China and Colombia reflect strong political, commercial, cooperation and investment ties for more than 40 years. This relationship has been strengthened in the framework of the current pandemic, especially thanks to various donations granted by the Chinese Government to Colombia. China delivered a donation of bio-safety material, respirators and diagnostic tests to Colombia, worth 1.5 million dollars, under the premise of union and solidarity in the midst of the COVID-19 pandemic. The Chinese embassy also donated thousands of food supplies for Colombian households affected by the pandemic (Colombia, 2020). 
Likewise, and from cities such as Medellín, the use of resources created in China has been promoted to share good practices or lessons learned; understanding that access to this information can be useful in the fight against COVID-19. The Cooperation Agency of the city of Medellín (ACI) and the Presidential Cooperation Agency of Colombia (APC), are also promoting among medical personnel and researchers the use of the Global MediXchange, a platform created by the Jack $\mathrm{Ma}$ and Alibaba Foundations in alliance with Chinese companies and universities (Agencia de Cooperación e Inversión de Medellín, 2020). The initiative seeks to facilitate online communication and collaboration to share practical experiences on the fight against the pandemic by offering free tools for medical personnel and scientists such as:

Resource Sharing Center: The medical personnel can access the COVID-19 Prevention and Treatment Manual published by the Hospital of the University of Zhejiang (China), which treated more than 100 confirmed cases without registering any deaths, misdiagnosis or infection of medical personnel. This manual is currently available in Chinese, English, Italian, French, Spanish, and Japanese, and will soon be translated into German, Persian, and other languages.

International Center for Communication of Medical Experts: Medical staff from around the world can communicate with Chinese doctors to individually share their anti-epidemic experience, or participate in live streaming activities hosted by Chinese hospitals, including Wuhan.

Exchange of practical experiences of front-line medical experts: Experts exchange knowledge and good practices through seminars and video conferences on experiences of medical personnel.

COVID-19 Technology Center: from the center and through solutions supported by advanced technology, it seeks to support the world in the fight against COVID-19. This initiative between China and Colombia is about building capacities through knowledge transfer and financial assistance, which are two modalities of South-South cooperation, according to what was stated by Chaturvedi (Chaturvedi, 2016). In this sense, it can be seen that the Chinese government has supported Colombia during this pandemic through medical resources, food, and above all: exchange of knowledge, which has strengthened the relationship between both countries and supported the cooperation towards shared interests and global issues.

\section{Mercosur Approved Emergency Fund for COVID - 19}

During the situation of COVID - 19, South - South cooperation has become a tool to overcome the challenges of the emergency situation among the Global South, where capacity building is the key to connect emergency response with financing mechanisms. Mercado Común del Sur (Mercosur) partners recognized the difficult situation shared by the countries involved and decided to use a regional fund called "FOCEM", as an instrument to facilitate regional cooperation for a better understanding and enhance information sharing, collaboration in scientific research and diplomatic relations during the COVID-19 pandemic.

El Fondo para la Convergencia Estructural del Mercosur (FOCEM), was created on the framework of the Mercosur agreement on 17th July 2006 with the Decision CMC 45/04 and is the first solidarity financing mechanism of the Mercosur countries. Its objective is to reduce the asymmetries of the block, finance projects to promote structural convergence, develop competitiveness and promote social cohesion. Among this structure, it also supports the 
functioning of the institutional structure and the strengthening of the integration process (Mercosur, 2020c)

FOCEM approved a contribution of an additional US $\$ 16,000,000$ for a Plurinational project of research, education and bio-technologies applied to health, which were allocated entirely to coordinate the fight against COVID-19. A first batch of US $\$ 5,800,000$ is available to strengthen the virus diagnostic capacity, with the purchase of equipment, supplies and materials (Mercosur, 2020c). This equipment is for the protection of operators and kits for rapid detection of COVID - 19. On the other hand, the new funds allowed the development of a serodiagnostic technique that detects the antibody response of patients, whether symptomatic or asymptomatic, in order to know the degree of penetration that the pandemic has had in the population.

El Instituto Pasteur from Uruguay, also benefited economically from the fund. To continue working on the COVID - 19 diagnosis and serodiagnosis, the institute received 2.7 million dollars from FOCEM. With this fund, Uruguay promised to produce serodiagnosis kits for Argentina and Paraguay in a total of 160.000 units. This example is related to innovation science diplomacy schemes, in order to create awareness about the current situation. This initiative demonstrates the importance of South-South cooperation projects for regional integration, as stated by Bergamaschi \& Tickner (Tickner, 2017). Furthermore, these circumstances justify the presence of science diplomacy to address health security and improve government relations, which have been unsuccessful to fulfill the pandemic situation.

Capacity building recognizes the exchange of knowledge among scientists of all around the world, with the purpose to have the primary role to reduce the improvisation of emergency response and hence reduce the risk of the emergency as suggested, but that responsibility should be shared with other stakeholders. However, not everything is about reducing the risk of emergencies, but supporting countries in its implementation, monitoring and sharing what works in reducing existing improvisation of the emergency response and preventing the creation of new risks. It is necessary to create socio-economic plans post COVID-19 with the best practices of the governments which led this emergency far better.

The presidents of the member countries of El Foro para el Progreso de América del Sur (Prosur) agreed on Monday, March 16, 2020 in a video-conference to protect their borders and promote joint purchases of medical supplies in the face of the spread of the new coronavirus in the region. The heads of state decided to "protect the borders in a coordinated and effective manner, facilitate the return of nationals to their respective countries and promote joint purchases of medical supplies to access better conditions," said a statement released by the government of the Chilean president, Sebastián Piñera (El Comercio, 2020).

In addition, further initiatives on emergency response were taken by La Organización Panamericana de Salud called on all countries in the Region of the Americas to take immediate measures to reorganize their health services and protect health professionals in order to safely care for patients with coronavirus disease (COVID-19) and save lives (Roa \& De Santana, 2012).The presidents of countries part of the Mercado Común del Sur (Mercosur) in Latin America agreed on a series of measures in the framework of the fight against the spread of the coronavirus in the region. The leaders agreed on the need to lower tariffs on medical devices. The authorities of the Federative Republic of Brazil, of the Republic of Paraguay, of the Uruguay Republic and of the Argentine Republic, spoke by video-conference to address the problem 
surrounding Covid-19. Among the leaders' decisions, a possible reduction in the prices of products and supplies for disease prevention and health care stands out, in the framework of the health emergency caused by Covid-19 and it was agreed to exchange statistics on the evolution of the virus, address border measures, guarantee the movement of goods and try to repatriate compatriots (Mercosur, 2020a).The Executive Boards of the World Bank and the Board of Directors of the International Finance Corporation (IFC) approved an increase that brings the accelerated disbursement financing package to USD 14 billion to help companies and countries in their efforts to prevent, detect and attack the rapid spread of COVID-19. This package will strengthen national public health preparedness systems, particularly with regard to containment, diagnosis and treatment of the disease. IFC, a member of the World Bank Group, will increase its COVID-19 related funding from $\$ 6$ billion to $\$ 8$ billion, as part of the total $\$ 14$ billion package, to help private companies and employees affected by the slowdown of the economy that generated the expansion of the disease (World Bank, n.d.).It is also important to mention that the aid of international cooperation should be addressed to achieve universal health coverage and sustainable financing for health, especially in developing countries. With the support of scientists working together in the same line in all the countries, the response of emergencies such as the novel coronavirus could be more planned and less unexpected. Besides, as stated by Fedoroff, scientific collaborations are the key in order to address the problems facing the 21st century (Fedoroff, 2009).

In the presence of these particular circumstances, Latin American governments should encourage the strengthening of the support of international cooperation in this matter and prioritize South - South cooperation in their national plans. In order to build capacity to face unexpected situations within the global south and with the purpose to aggregate new cooperation schemes to meet new needs, it is necessary to take into account the preservation of the cultures and local diversities, as stated by Carrillo Roa \& Santana (Roa \& De Santana, 2012). Science in Diplomacy plays an important role for conducting research to draft new guidelines for public policies allowing the integration of the work of scientists into the foreign policies. Scientists all over the world are permanently in contact with those who are in this region to provide useful information. The interaction between actors in different dimensions is also necessary because of their important work in the areas of scientific research, technological development, and innovation. The current global emergency situation involves the improvement of initiatives regarding Public Health Emergency of International Concern (PHEIC), which establishes a new challenge for Science Diplomacy. In this sense, the Swiss Academy of Medical Sciences states the relevance of building sustainable collaborations for health issues through science diplomacy schemes, in order to promote the quality of health services in the globe (Swiss Academy of Medical Science, 2013).

\section{Conclusion}

The world is facing a health crisis without precedent; the COVID-19 pandemic has exposed the weaknesses of our health systems in Latin America and the importance of international cooperation. The emergency response plans in a governmental scheme have been insufficient and the South-South Cooperation still has an important role to play. The principles of South-South Cooperation are ideal to form horizontal multi-stakeholder collaboration spaces 
that allow the countries to respond to global challenges. Besides, many Latin American countries face structural obstacles such as the lack of capacity to manage migration issues, persistent institutional weaknesses, inequalities, low investment in human capital, among others. The initiatives and projects regarding South - South Cooperation are focused in fostering the development and transfer of technologies, promoting collaborative programs to develop practices taking into account social realities, strengthen public institutions of research, academic institutions, study centers, knowledge networks and regional or thematic centers of excellence and improve access to finance with donors.

Science in diplomacy plays an important role for conducting research to draft new guidelines for public policies allowing the integration of the work of scientists into the foreign policies. Scientists all over the world are permanently in contact with those who are in this region to provide useful information. The interaction between actors in different dimensions is also necessary because of their important work in the areas of scientific research, technological development, and innovation. The current global emergency involves the improvement of initiatives regarding Public Health Emergency of International Concern (PHEIC), which establish a new challenge for Science Diplomacy.

In terms of financial scientific initiatives to create technological knowledge, Latin American countries, specifically lower middle-income countries like Central America lack the necessary financial resources to foster scientific or technological projects with their own budget. However, a good place to start is to produce local talents and capacity building to lead the scientific policies, science diplomacy strategies and include South-South Cooperation in the national plans. Disparities within and among countries in the region, is an important point to take into account by policy makers and South - South Cooperation initiatives, with the purpose to promote a suitable and real sustainable development. If researchers, scientists, diplomats, policymakers work together in the same path, the response of emergencies such as the novel coronavirus could be more planned and less unexpected. It is time to develop capacity over the weaknesses.

\section{References}

Adolin, B. N. (2020). Southern Perspectives on Science Diplomacy. In Southern Perspective on Science Diplomacy (pp. 71-74). New Delhi: RIS.

Balakhrisnan, B. (2018). Technology and International Relations. Challenges for the 21st Century. New Delhi.

Cabot, E. A. (2014). Una aproximación a la concepción de ciencia en la contemporaneidad desde la perspectiva de la educación científica. Ciência \& Educação (Bauru), 20(3), 549-560. https://doi.org/10.1590/1516-73132014000300003

Chaturvedi, S. (2016). The Development Compact: A Theoretical Construct for South-South Cooperation I Research and Information System For Developing Countries. New Delhi. Retrieved from https://www.ris.org.in/development-compact-theoretical-construct-south-southcooperation

Colombia, G. de. (2020). Colombia recibe donaciones de China por 1,5 millones de dólares para enfrentar covid-19. Retrieved September 19, 2020, from https://id.presidencia.gov.co/Paginas/prensa/2020/Colombia-recibe-donaciones-de- 
China-por-1-5-millones-de-dolares-para-enfrentar-covid-19-200507.aspx

Dados, N., \& Connell, R. (2012). The Global South. Contexts, 11(1), 12-13. https://doi.org/10.1177/1536504212436479

de Renzio, P., \& Seifert, J. (2014). South-South cooperation and the future of development assistance: mapping actors and options. Third World Quarterly, 35(10), 1860-1875. https://doi.org/10.1080/01436597.2014.971603

El Comercio. (2020). South American countries agree to protect borders and buy medical supplies due to coronavirus | Trade. Retrieved September 19, 2020, from https://www.elcomercio.com/actualidad/paises-sudamerica-proteccion-fronterascoronavirus.html\#cxrecs_s

Fedoroff, N. V. (2009, January 9). Science Diplomacy in the 21st Century. Cell. Cell Press. https://doi.org/10.1016/j.cell.2008.12.030

Gluckman, P., Turekian, V., Grimes, R., \& Kishi, T. (2017). Science Diplomacy: A Pragmatic Perspective from the Inside | Science \& Diplomacy. Retrieved September 19, 2020, from https://www.sciencediplomacy.org/article/2018/pragmatic-perspective

Gustavo, R., \& Degaldo, M. (2019). Co-development and Global Political Economy (GPE): The Role of the South - South Cooperation.

Hassan, M. (2020). STI Cooperation in Arab Countries: Challenges and Opportunities. In Research and Information System for Developing Countries (Ed.). In Southern Perspectives on Science Diplomacy (pp. 59-62). New Delhi: RIS.

Jaramillo, J., \& Vera Lugo, J. P. (2013). View of Ethnographies from and about the global South. Introductory Reflections. Universitas Humanística. Retrieved from https:// revistas.javeriana.edu.co/index.php/univhumanistica/article/view/5957/4807

Martín Faus, C. D. (2015). La Cooperación Sur-Sur y el desarrollo del Sur global. Universitat Autònoma de Barcelona. Retrieved from https://www.tdx.cat/handle/10803/291818\#page=1

Mercosur. (2020a). Mercosur allocates an emergency fund of 16 million dollars to combat COVID-19 in the region - Mercociudades. Retrieved September 19, 2020, from https://mercociudades.org/mercosur-asigna-fondo-de-emergencia-de-16-millones-dedolares-para-combatir-el-covid-19-en-la-region/

Mercosur. (2020b). The Contribution to the Pasteur Institute of Montevideo and its contribution to the fight against COVID 19.:: FOCEM. Retrieved September 19, 2020, from https:// focem.mercosur.int/es/noticia/el-aporte-al-instituto-pasteur-de-montevideo-ysu-contribucion-al-combate-al-covid-19/

Mercosur. (2020c). What is FOCEM :: FOCEM. Retrieved September 19, 2020, from https://focem.mercosur.int/es/que-es-focem/

Mostafa Safdari Ranjbar, M. E. (2019). (PDF) Science Diplomacy in Iran: Strategies and Policy Alternatives in the Making. Science Diplomacy Review. Retrieved from https://www.researchgate.net/publication/335756776_Science_Diplomacy_in_Iran_St rategies_and_Policy_Alternatives_in_the_Making

Roa, A. C., \& De Santana, J. P. (2012). Regional integration and south-south cooperation in health in Latin America and the Caribbean. Revista Panamericana de Salud Publica/Pan American Journal of Public Health, 32(5), 368-375. https://doi.org/10.1590/S102049892012001100007 
Royal Society. (n.d.). GCSA: Guidelines on scientific analysis in policy making | Royal Society. Retrieved September 19, 2020, from https://royalsociety.org/topicspolicy/publications/2005/scientific-policy-making/

Swiss Academy of Medical Science. (2013). (No Title). Geneva, Swiss. Retrieved from https://www.graduateinstitute.ch/sites/internet/files/2019-

02/Report_6thHLS_v5_web.pdf

Tickner, I. B. and A. B. (2017). Introduction: South-South Cooperation Beyond the Myths-A Critical Analysis. LOndon: Palgrave Macmillan.

United Nations. (2016). The Global Guardian of Public Health.

United Nations. (2020). Capacity-building | Academic Impact. Retrieved September 21, 2020, from https://academicimpact.un.org/content/capacity-building

Vadell, J., Lo Brutto, G., \& Leite, A. C. C. (2020). The chinese south-south development cooperation: An assessment of its structural transformation. Revista Brasileira de Politica Internacional, 63(2). https://doi.org/10.1590/0034-7329202000201

WHO. (2017). WHO | IHR Procedures concerning public health emergencies of international $\begin{array}{llll}\text { concern } & \text { (PHEIC). } & \text { WHO } & \text { Retrieved }\end{array}$ http://www.who.int/ihr/procedures/pheic/en/

World Bank. (n.d.). World Bank Group Response to COVID-19 Increases to \$ 14 Billion to Help Sustain Economies and Protect Jobs. Retrieved September 21, 2020, from https://www.bancomundial.org/es/news/press-release/2020/03/17/world-bankgroup-increases-covid-19-response-to-14-billion-to-help-sustain-economies-protectjobs 